\title{
Lucky Marais: Die verpersoonliking van kameleontiese manlikheid
}

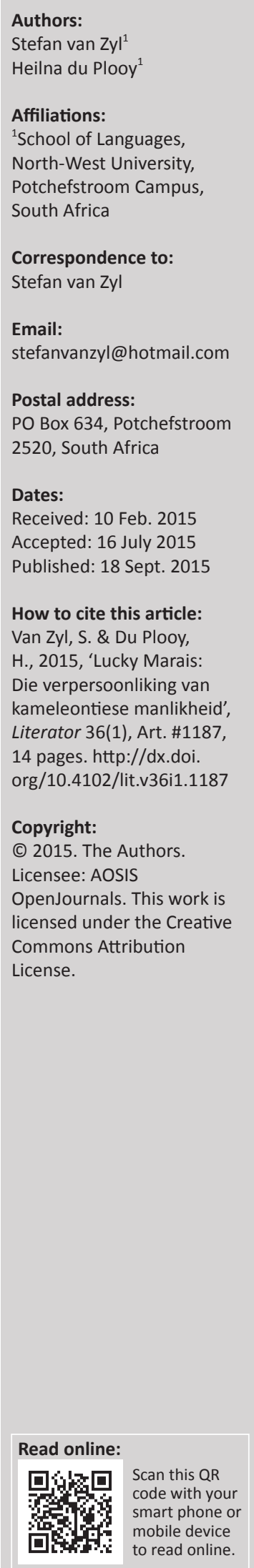

Hierdie artikel fokus op die representasie van manlikheidsbeelde in Eben Venter se roman Santa Gamka (2009) en meer spesifiek op die uitbeelding van die veelfasettigheid van manlikheid in die hoofkarakter Lucky Marais. Die werkbaarheid van die kognitiewe narratologie as literêre benadering word ook getoets deur kognitiewe rame en skripte in die roman te identifiseer. Die ruimtes waarin gebeure afspeel en die manier waarop handelinge en gebeure uitgebeeld word, word in verband gebring met bekende rame en skripte. Die veronderstelling is dat die teksgegewe op die eerste vlak geplaas word binne die raamwerke van bekende kognitiewe skripte en dat bepaalde manlikheidsbeelde dus potensieel op die manlike hoofkarakter geprojekteer kan word. Hierdie projeksies kan egter deur die verhaal ondermyn word. Daar is volgens die kognitiewe teorie potensiële prosesseringsmoontlikhede wat tydens die lees van ' $n$ narratief in werking kan tree. Eerstens kan die narratief sterk op die leser inwerk sodat bestaande idees en persepsies verwerp word en daar ruimte ontstaan vir nuwe idees en persepsies in ooreenstemming met die uitbeelding in die narratief; tweedens kan bestaande idees gewysig word deur die kognitiewe prosessering van inligting in die roman; en derdens kan dit gebeur dat die nuwe idees onderliggend aan die handelinge en gebeure in die narratief in geheel verwerp word. Die moontlikheid bestaan dus dat, ongeag in welke mate dit plaasvind, die kognitiewe prosessering van die inligting in die roman 'n uitwerking kan hê op die leser. In hierdie geval kan die representasies van manlikheid in die roman dus potensieel 'n effek hê op die manier waarop die leser manlikheid in die toekoms in die werklike lewe ervaar. Venter toon ' $n$ fyn aanvoeling en deernis vir die karakters in sy romans en die hipotetiese verwagting is dat die skrywer daarin slaag om by die leser ' $n$ soortgelyke aanvoeling en deernis te ontwikkel vir die hoofkarakter in Santa Gamka. Die roman kan dus 'n beter begrip van sowel menslikheid as manlikheid bewerkstellig omdat manlikheid op bepaalde maniere uitgebeeld word. Die oogmerk van die artikel is om aan te toon dat die kognitiewe narratologie gebruik kan word om die aandag te vestig op die manier waarop die roman bestaande en gevestigde rame en skripte ten opsigte van manlikheid ondermyn deur die uitbeelding van die gekompliseerde persoonlikheid van Lucky Marais.

Lucky Marais: The epitome of chameleontic masculinity. This article focuses on the representation of masculine images in Eben Venter's novel Santa Gamka (2009) and more specifically on the multifaceted representation of masculinity in the main character Lucky Marais. The effectivity of the cognitive narratology as literary approach is also tested by identifying cognitive frames and scripts in the novel. The spaces in which events take place and the manner in which actions and events are represented are interpreted according to known frames and scripts. The premise is that textual information is initially understood within the frameworks of known cognitive scripts and that certain fixed masculine images have the potential to be projected onto the male main character. These projections can however be undermined by the narrative. According to the cognitive theory there are potential processing possibilities that can be activated during the reading of a narrative. Firstly, the narrative manipulates or entices the reader to reject existing ideas and perceptions and to create a space for new ideas and perceptions in concordance with the representation in the narrative; secondly existing ideas can be altered by the cognitive processing of information in the novel; and thirdly it can happen that new ideas, underlying the actions and events in the narrative, are completely rejected. The possibility therefore exists that, regardless of the extent to which it takes place, the cognitive processing of information in the novel will have an effect on the reader. In this case the representations of masculinity in the novel may have a potential effect on the manner in which the reader experiences masculinity in future real-world situations. Venter demonstrates sensitivity and compassion for all the characters in his novels and the hypothetical expectation is that the author succeeds in the development of a similar sensitivity and compassion for the main character in Santa Gamka. The novel can thus lead to a better understanding of both humanity and masculinity because of the way in which masculinity is represented. The goal of the article is to show that cognitive narratology can be used to focus the attention on the manner in which the novel undermines existing and established frames and scripts with regard to the representation of the complex personality of Lucky Marais. 


\section{Inleiding}

Geslagsrolle was nog altyd 'n belangrike aspek van die menslike lewe, maar sedert die begin van die twintigste eeu word daar, binne die denkraamwerke van die Modernisme, buitengewoon baie aandag gegee aan hierdie vraagstuk. Daar word onderskei tussen geslagtelikheid en gender, en laasgenoemde word binne verskillende dissiplines en vanuit verskillende perspektiewe ondersoek. Die rede hiervoor is dat idees oor gender, veral die aard van manlikheid en vroulikheid, bepaal word deur verskillende psigologiese, sosiologiese, politieke, kulturele en historiese kontekste. Vanweë die kompleksiteit en veelheid van opvattings en die sterk nawerking van gevestigde denkpatrone is sienings van en standpunte oor genderverwante kwessies dikwels inkonsekwent en vaag.

Volgens Visagie (2004:2) is die uitbeelding van manlikheid in die letterkunde lank nie meer ' $n$ vanselfsprekende en deursigtige gegewe nie. 'n Letterkundige studie van 'n genderkonstruk soos manlikheid is dus 'n uitdaging. In hierdie artikel word daar op manlikheidsbeelde in die roman Santa Gamka as literêre teks gefokus met die veronderstelling dat die aard van die literatuur as 'n spesifieke vorm van estetiese ekspressie en kommunikasie die gesprek bepaal. Verwysings na ander dissiplines en benaderings is daarom slegs sydelings te sprake. Die doel van hierdie artikel is om ondersoek in te stel of die kognitiewe narratologie 'n werkbare metode verskaf om insig te verkry in die verskuiwing van rame en skripte deur middel van 'n narratiewe literêre teks, sonder om 'n empiriese, sosiologiese of antropologiese studie te moet uitvoer, en ook sonder om in stereotipes te verval. Die aanname is dat manlikheidsbeelde in literêre tekste ontleed kan word met behulp van die kognitiewe konsepte van rame en skripte op 'n manier wat dit moontlik maak om 'n gesprek te voer oor die verhouding tussen vermeende geykte sieninge en verstaansraamwerke en die representasies in die teks. ${ }^{1}$

Lucky Marais in Santa Gamka (2009) deur Eben Venter kan, bolangs beskou, gesien word as die vergestalting van manlike vryheid en ook losbandigheid. Lucky se 'beroep' vestig die aandag eksplisiet op die seksuele gedrag van verskillende belangrike en minder belangrike mense in die denkbeeldige dorpie, Santa Gamka, in die Karoo, waar hy as 'n rent boy sy dienste verskaf. By elkeen van sy sewe kliënte kom 'n ander aspek van Lucky se persoonlikheid en ook van sy manlikheid na vore. Hy oorskry sosiaal gekonstrueerde grense soos dié van ras, seksualiteit, ekonomiese klas en politieke status wanneer hy aan sy kliënte se behoeftes voldoen. Die roman begin waar Lucky hom in 'n pottebakkersoond bevind en sy verlede in die kort tydjie wat hy het voordat die oond te warm word, voor hom afspeel. Sy vyande is mense wat hom as ' $n$ bedreiging beskou omdat hy te veel weet en omdat hul geliefdes hom 'gebruik' of selfs 'verkies'. Hulle wil hul

\footnotetext{
1.Hierdie artikel is gebaseer op ' $n$ ongepubliseerde verhandeling: Van Zyl (2014) 'Die representasie van veelfasettige manlikheidsbeelde in die romanoeuvre van 'Die representasie van veelfasettige manlikheidsbeelde in die romanoeuvre van Eben Venter, onder die studieleiding van prof. Heilna du Plooy. Vir verwerking en aanhalings is veral gebruik gemaak van Hoofstuk 2-4. Hiermee word ook di finansiële bydrae van die National Research Foundation (NRF), die NoordwesUniversiteit (NWU) en die NWU Skool vir Tale se Navorsingseenheid: Tale \& Literatuur in die Suid-Afrikaanse konteks erken.
}

mag bewys deur van hom 'n voorbeeld te maak. Dit is binne hierdie bakoond dat hy die laaste sewe minute van sy lewe aftel, en sy herinneringe en gedagtes maak die grootste deel uit van die roman. Danksy ' $n$ kragonderbreking verbrand hy egter nie, en gaan hy saam met Eddy en Eamonn, sy Ierse vriende, na Amerika. Op die lughawe word die driemanskap egter voorgekeer en gearresteer. Die roman eindig waar Eddy en Eamonn vrygelaat word en Lucky alleen agterbly.

Omdat Lucky as karakter verskillende rolle vertolk wanneer en soos omstandighede dit vereis, kom hy na vore as ' $n$ man wat as 't ware verskillende persoonlikhede in hom dra, of die potensiaal het om homself kameleonties aan te pas by omstandighede. Sy optrede druis dus in teen tradisionele sieninge van identiteit en manlikheid. Die diskrepansie tussen aanvaarde opvattinge en Lucky se gedrag maak dit logies om die roman te probeer ondersoek vanuit die kognitiewe narratologie waarin die werking van kognitiewe rame en skripte die belangrikste uitgangspunt vorm. In hierdie artikel word daar dus eerstens aandag gegee aan die konsep van skemata met besondere verwysing na kognitiewe rame en skripte soos wat in die kognitiewe narratologie beskryf en gebruik word. Daarna word 'n kort oorsig van manlikheidsbeelde gegee. Die konsepte van rame en skripte word dan gebruik om geselekteerde aspekte van manlikheidsbeelde in die roman te bespreek. Die artikel is nie daarop gerig om ' $n$ uitvoerige bespreking van Venter se oeuvre te gee of om die roman Santa Gamka uitvoerig te ontleed nie. Dit is eerder ' $n$ verkennende ondersoek na die kognitiewe metode om te kyk of hierdie benadering in die ontleding en interpretasie van 'n narratiewe teks tot bruikbare gevolgtrekkings kan lei.

\section{Teoretiese uiteensetting ' $n$ Kort oorsig van die kognitiewe narratologie}

Die doel van die gebruik van die kognitiewe narratologie ${ }^{2}$ as benadering tot die roman in hierdie artikel het ten doel om te toon hoe bestaande idees en stereotipes bevestig of gedestabiliseer word deur die narratiewe strategieë wat skrywers in romans gebruik. Hierdie werkwyse volg daaruit dat die kognitiewe narratologie daarop gerig is om die mentale prosesse waardeur narratiewe geprosesseer en verstaan word, te beskryf en te ontleed. Karakters is representasies van mense, en die herkenning van bekende patrone in gebeure en handelinge stel lesers in staat om verhale te verstaan. In 'n omgekeerde proses maak lesers as mense ook afleidings oor hul eie en ander mense se gedrag en gedagtes deur hulself, en die mense om hulle, as karakters in 'n narratief te konstrueer (Herman 2003:3). Afgesien van die begrip en interpretasie van 'n verhaal, en na aanleiding van kennis van bekende skemata of betekeniskonstrukte in die werklikheid, gebeur dit ook dat mense dikwels identifiseer met die karakters in die verhale wat hulle lees. Hulle kan hulle in dieselfde situasies en agtergronde indink en ook vereenselwig met die karakters binne hierdie narratiewe. Die outeur het dus die geleentheid om met sy of haar verhaal 
sekere idees en voorstellings van sommige lewensaspekte te representeer. Dit kan gebeur deur die bevestiging van die rame en skripte (soos wat in populêre literatuur dikwels gebeur), of op innoverende en kreatiewe maniere ten einde die leser van die narratief se aandag te behou en ook moontlik sy of haar idees en gedagtes te wysig tydens die lees van die verhaal.

Herman (2003:3) gebruik Todorov se konsep van die narratiewe trajek om te toon hoe die kognitiewe narratologie literêre verstaanprosesse beskou. Narratiewe volg prototipies 'n trajek wat beweeg vanuit ' $n$ toestand van ekwilibrium deur ' $n$ fase van disekwilibrium tot 'n eindpunt waar die ekwilibrium weer herstel. Na analogie van hierdie trajek kan die proses beskryf word van hoe 'n leser 'n teks ervaar en begryp. Die leser benader gewoonlik' $n$ teks op een spesifieke manier, maar sy of haar idees kan moontlik verander ná die lees daarvan. Die leser kom met sy of haar bestaande idees na die teks (ekwilibrium) en word binne die teks gekonfronteer met nuwe idees wat dalk in teenstelling is met die reeds bestaande idees. Daar volg dus ' $n$ fase van disekwilibrium waartydens die leser die keuse het om hierdie mentale wysigings in sy of haar denke te aanvaar of te verwerp of gedeeltelik te aanvaar of te verwerp. Hierdie veranderinge of wysigings van bestaande idees en voorstellings kan neerslag vind in die manier waarop die leser oor sekere sake dink of voel. Nadat die leser die narratiewe teks gelees het, gaan hy of sy stelselmatig weer ' $n$ fase van ekwilibrium binne waarin die nuwe idees deel uitmaak van sy of haar bestaande idees, maar dit kan natuurlik ook gebeur dat so 'n leser bloot bly by die reeds bestaande idees.

Twee konstrukte wat 'n kardinale rol speel in kognitiewe psigologiese teorieë is prosesse en representasies (Gerrig \& Egidi 2003:34). Prosesse is die mentale werking wat lesers in staat stel om die sprong van simbole op ' $n$ bladsy na uitgebreide (verbeelde) storiewêrelde te maak, terwyl representasies die produkte van hierdie mentale prosesse is wat vir 'n sekere tydperk in die geheue gestoor word. Sommige van hierdie representasies bly redelik naby aan die besonderhede van ' $n$ teks, maar ander is meer uitgebreid en gebaseer op die vermenging van teksinligting met inligtingsbronne buite die teks. Met betrekking tot die representasie van manlikheidsbeelde is dit dus so dat die leser ekstratekstuele kennis het wat berus op opvattings waarmee die leser in sy lewe op verskeie maniere gekodeer is, maar gekonfronteer kan word met tekstuele inligting wat afwyk van die ekstratekstuele kennis. Hierdie verskille sal veroorsaak dat die leser voor die keuse te staan kom om sy of haar bestaande idees te wysig óf die nuwe kennis te verwerp of gedeeltelik of volkome te aanvaar.

Kognitiewe narratologie kan beskou word as 'n interdissiplinêre benadering wat ten doel het om lesers se leeservarings van narratiewe te ondersoek en veral te fokus op die effek wat inligting binne narratiewe op die lesers daarvan het. Dit is daarop ingestel om die prosesse waardeur narratiewe geprosesseer en verstaan word, te beskryf en te ontleed. Die benadering dwing dus ' $n$ bepaalde soort lees af wat betref die manier waarop die narratiewe inhoud van 'n roman verstaan en nagevors word, en hierdie proses sluit dus ' $n$ fokus op sowel die teks as die waarskynlike leser in. Die kognitiewe narratologie is ' $n$ benadering binne die postklassieke narratologie wat die ideale of geïnternaliseerde konstrukte van rame en skripte gebruik om die narratiewe trajek te bestudeer.

\section{Skemata}

In die vroeë fases van kognitiewe psigologiese navorsing, waaruit die kontemporêre kognitiewe narratologie ontwikkel het, was teoretici begaan oor die maniere waarop lesers geheuestrukture gebruik om hul narratiewe ervarings te versterk (Gerrig \& Egidi 2003:40). Die aanname is dat inligting uit die werklikheid georden en in klusters saamgegroepeer word ten einde hergebruik te kan word in latere prosesse van onthou en verstaan. Hierdie klusters of eenhede word beskou as kognitiewe skemata wat inhoudelik en struktureel ervarings (mense, plekke, dinge) in eenhede versamel en dan verder funksioneer gedurende narratiewe en enige ander kommunikatiewe ervarings. Lesers se kennis en (her-)gebruik van skemata verskaf ten minste twee voordele aan outeurs: in die eerste plek laat dit outeurs toe om ' $n$ toneel met vinnige handelings en toneelverskuiwings uit te beeld (omdat lesers dit ken en kan verstaan) en in die tweede plek laat skemata outeurs toe om aandag te skenk aan afwykings van die norm. Daar is egter sommige gevalle waarin die beskikbare skemakonstruksies beperk en dus onvoldoende is - veral in die geval van oomblik-tot-oomblikteksprosessering. So kan dit wel gebeur dat al die inligting waaroor ' $n$ leser aangaande ' $n$ spesifieke onderwerp beskik, nie deel van ' $n$ voortgaande representasie van ' $n$ teks word nie. Teksrepresentasies reflekteer ' $n$ vermenging van die werklike woorde van 'n teks en die gevolgtrekkings wat lesers enkodeer gebaseer op daardie woorde.

Skemata word deur narratoloë gebruik om 'n teks te interpreteer waar die diskoers self nie al die nodige inligting verskaf om verstaan te kan word nie (Emmott \& Alexander 2011). Op grond van bekende skemata vul die lesers ontbrekende inligting aan. Kognitiewe skemata is dus van kardinale belang om koherensie in ' $n$ teks te bewerkstellig. Wanneer veranderende omstandighede en nuwe gebeure bestaande skemata weerspreek of dit ongenoegsaam bewys, kan daar nuwe veralgemenings gemaak word (Emmott \& Alexander 2011; Margolin 2003:277). Die verhouding tussen literêre tekste en skemata is dus tweeledig: terwyl dit reëls neerlê en die apparatuur vir die begrip en interpretasie van 'n teks verskaf, kan die teks self ook daartoe bydra dat lesers bestaande skemata wysig of selfs nuwe skemata skep.

Vorige ervarings vorm gestruktureerde repertoires van verwagtinge van huidige en ontluikende ervarings en hierdie repertoires word in die geheue gestoor (Herman 1997:1047). Dit is duidelik dat die brein uit ' $n$ groot, maar nie-oneindige (dit bly wel beperk) aantal ervaringsrepertoires van beide statiese (rame) en dinamiese (skripte) aard, inligting kan onttrek (Herman 1997:1047). Statiese repertoires help om 
byvoorbeeld 'n koppie van 'n beker en 'n perd van 'n trekker te onderskei, terwyl dinamiese repertoires help om te weet hoe gebeure tipies ontvou gedurende alledaagse geleenthede soos troues. Dit help ook dat sodanige geleenthede nie met mekaar verwar word nie.

Gapings staan sentraal in narratiewe fiksie omdat die materiaal wat die teks vir die rekonstruksie van 'n fiksionele wêreld verskaf, nie genoeg is nie (Rimmon-Kenan 1994:127). Met behulp van rame en skripte kan hierdie gapings gevul word met voorafkennis waaroor die leser reeds beskik. Rame en skripte is dus soorte kognitiewe skemata wat lesers se interpretasies van spesifieke situasies, deelnemers en gebeure lei. Daar is egter wel die wins daarin vir die lesers dat, soos wat die narratiewe wêreld ontvou, die teks die lesers kan lei (of selfs dwing) om die interpretatiewe modelle waarop hulle tot dusver gesteun het, aan te pas of te verskuif (Jahn 1997, 1999).

Die oorspronklike definisies van rame en skripte oorvleuel en komplementeer mekaar in baie opsigte (Jahn 1999:174). Beide konstrukte het te doen met verwagtings, aannames, veronderstellings, afleidings en vooropstellings. Die beste manier waarop hierdie konsepte onderskei kan word, is om te verstaan dat rame ' $n$ breër konsep as skripte is, aangesien skripte as spesifieke soorte rame beskou word. Soos Palmer (2004:47) dit stel: Skripte word binne kognitiewe rame gebruik om ons daaglikse gedrag te lei en sluit ook die verstekmeganisme in wat kenmerkend is van rame. Wanneer ons verwagtinge verkeerd bewys word, word ons gedwing om te improviseer, en beide rame en skripte fasiliteer hierdie kognitiewe proses.

Rame en skripte funksioneer dus binne ' $n$ verhouding van wedersydse afhanklikheid en versterking wat ' $n$ voorbeeld is van wat as ' $n$ hermeneutiese sirkel beskryf kan word. Aan die een kant skep rame en skripte die moontlikheid vir data om sin te maak en te akkumuleer, en aan die ander kant toets die data die vermoë van die rame en skripte wat aktief is (Jahn 1999:176). Met ander woorde, die rame en skripte dui aan wat die teksgegewens is en die teksgegewens dui op hulle beurt aan of die keuse van rame of skripte gepas is.

Dit is belangrik om in gedagte te hou dat hierdie skemata nie totaal vaste strukture is nie, aangesien mense dikwels dit wat hulle lees, verkeerd rekonstrueer, representeer en verstaan. Vervolgens word die twee konstrukte afsonderlik bespreek ten einde te toon dat dit nie slegs 'nuwe name vir ou konsepte' is nie, maar selfstandig gebruik kan word om 'n literêre teks op kognitiewe narratologiese manier te benader.

\section{Rame}

Palmer (2004:46) gee 'n kort oorsig van die verskillende benamings wat teoretici deur die jare aan rame gegee het. Dit sluit in mentale modelle (Johnson-Laird), waar die denke kleinskaalmodelle van die werklikheid konstrueer om gebeure te antisipeer, om te redeneer en om verduidelikings te onderlê; raamwerke (Freeman) wat 'n samehangende stel oortuigings, gedagtes en neigings is waarbinne wêreldperspektiewe ingeraam word; en geïnternaliseerde kaarte (Sterelny) waarvolgens mense in die sosiale en fisieke wêreld via die gekonstrueerde innerlike representasies navigeer.

Wanneer 'n individu 'n nuwe situasie ervaar (of een wat 'n merkbare verandering in standpunt meebring), selekteer hy of sy vanuit hul geheue ' $n$ bestaande en bekende struktuur (wat ' $n$ raam genoem word) aan die hand waarvan die situasie begryp kan word. Sulke raamwerke word onthou sodat dit aangepas kan word om beter by die realiteit in te pas en sodat besonderhede verander kan word soos nodig (Minsky 1974:1). Wanneer die leser van 'n teks 'n karakterisering aantref wat van die norm van daardie 'tipe' karakter afwyk, is dit dus heel moontlik dat 'n nuwe idee van daardie tipe karakter gevorm kan word. Die huidige raamwerk van die leser word aangepas om 'n ander perspektief te akkommodeer en sodoende 'n ryker betekenis aan die betrokke tipe karakter toe te ken.

Rame kompenseer op hierdie manier vir kontekstuele data binne ' $n$ teks aangesien tekste nie elke detail beskryf nie. So word gesuggereerde of onderliggende inligting in die fiksionele konteks deel van die leesproses. Die leser kan ook nie individuele sinne of groepe sinne buite die teks as geheel lees nie. Die brein bewerkstellig dus (deur middel van gestoorde kennisraamwerke) 'n brug tussen verskillende dele van 'n teks (Emmott 1994:165). Tekste word deur middel van rame toeganklik gemaak omdat al die rame tot die geheelbeeld en -idee van dit wat binne die teks gebeur, bydra. Die leser abstraheer dus op kognitiewe manier inligting uit die konteks van die teks ten einde ' $n$ begrip te ontwikkel vir die narratiewe elemente binne die teks.

\section{Skripte}

Volgens Schank en Abelson (1975:151) is 'n skript 'n struktuur wat 'n gepaste reeks gebeure in 'n spesifieke konteks beskryf. Waar die raam meer gefokus is op die herkenning van plekke waar dinge plaasvind, en omstandighede, fokus die skript meer op dit wat gebeur. Mercadal (1990:255) beskryf die skript as 'n beskrywing van hoe daar van 'n reeks gebeurtenisse verwag word om te ontvou en stel dat dit soortgelyk aan ' $\mathrm{n}$ raam is omdat skripte stelle verwagtings aktiveer. Rame verskil egter van skripte in dié opsig dat rame 'n sekere punt in tyd voorstel. Herman (2003:40-41) voer aan dat die konsep van skripte, naamlik die kennisrepresentasies met betrekking tot 'n verwante sekwens van gebeure of handelinge wat in die geheue gestoor is, ontwerp is om te verduidelik waarom mense komplekse interpretasies van stories kan opbou op grond van baie min tekstuele of diskoersaanwysings.

'n Skript kan dus beskou word as 'n hipotetiese kognitiewe struktuur wat begrip van gebeurtenisgebaseerde situasies organiseer wanneer dit geaktiveer word (Abelson 1981:717). Skripte is kennisstrukture en nie net ' $\mathrm{n}$ responsprogram nie, en daarom is toegang daartoe simbolies, dit wil sê as 
gestoorde taalrepresentasies, sowel as deur middel van direkte ervaring, oftewel soos wat dit deur ervaring aangeleer is (Abelson 1981:722).

In die afwesigheid van stereotipes wat gestoor is as skripte, sal lesers nie eers die mees basiese teksafleidings kan maak nie. Stories is egter nie slegs herkenbaar solank daar aan lesers vertel word wat hulle reeds weet nie, maar meer dikwels verskaf stories inligting wat kontrasterend of aanvullend is tot wat die lesers en aanhoorders weet. Stories fokus die aandag op die ongewone en merkwaardige dinge teen ' $n$ agtergrond wat uit patrone van oortuiging en verwagting bestaan (Herman 1997:1048). Om verhale te vertel is dus 'n manier om nuwe kennis met voorafbestaande kennis te versoen (Herman 1997:1048).

Elke vertelling vereis dat die luisteraar of leser skripte moet gebruik om die narratief te inisieer en sodoende mee te werk aan die totstandkoming van die storie. Die formele eienskappe van die sekwense beperk die soorte skripte wat in 'n verhaal aangedui kan word en dit beperk ook die aantal stories wat op enige bepaalde skript gebaseer kan word (Herman 1997:1051).

\section{Manlikheidsbeelde}

Uit hierdie uiteensetting volg dat gerepresenteerde vorme van manlikheid in 'n verhaal beoordeel en verstaan word op grond van bestaande opvattings van manlikheid, wat as rame en skripte in verstaanprosesse funksioneer. Sulke bestaande opvattings is egter afhanklik van die kulturele, religieuse, ideologiese en ook historiese omstandighede waarmee mense gekodeer word. Daarom is 'n kort oorsig van sieninge oor manlikheid hier ter sake.

Volgens Connell (2001:141) word die term 'manlikhede' (masculinities) gebruik om na die verskillende fasette of variante van manlikheid te verwys. Hy verwys ook na die spanning tussen hierdie manlikhede wat dikwels veroorsaak word deur die spanning tussen teenstrydige begeertes en praktyke. Die hoofkarakter in Santa Gamka vertoon deur sy optrede inderdaad uiteenlopende manlikheidsbeelde. Hy is inderdaad ' $n$ manlike kameleon wat sy handelinge aanpas by die omgewing en omstandighede waarin hy hom bevind. Die spanning tussen die 'aanvaarde' en bekende beeld van ' $n$ jong bruin man op 'n plattelandse Karoodorpie en die verskillende manlikheidsbeelde soos gerepresenteer in die roman is dus ' $n$ boeiende onderwerp om te bestudeer.

Die gangbare definisie van manlikheidsbeelde is dat dit om daardie beelde van manlikheid gaan wat in die samelewing uitgebeeld of uitgeleef word. Dit het te make met die voorkoms en handeling van mans en ook die manier waarop mans verskillende manlikhede in verskillende kontekste kan aanneem of projekteer-dit kan ook gebruik word as 'n masker waaragter hulle om verskeie redes kan skuil. Vervolgens sal verskeie van hierdie kontemporêre manlikheidsbeelde soos gesien in verskeie kontekste (maar wel met verwysing na die
Suid-Afrikaanse samelewing) aan die hand van opgetekende teorieë en standpunte bespreek word.

Om ' $\mathrm{n}$ man te wees beteken onvermydelik dat die man as mens 'n sekere rol moet speel. Manlikheid representeer 'n stel riglyne (rame) en 'toneelaanwysings' (skripte) wat mans moet leer uitvoer (Van der Watt 2007:54). Reeser (2010:22-23) wys daarop dat ' $n$ manlikheidsbeeld gestabiliseer kan word as ' $n$ mite wanneer dit so wyd verspreid aanvaar word dat 'n kultuur of kulture dit as vanselfsprekend as die geldige narratief vir manlikheid aanvaar. Wanneer sulke beelde oral aanvaar word, word dit universeel en op ' $n$ kulturele vlak sal dit as mites manifesteer, dit wil sê as rigtende navolgenswaardige voorbeelde of imago's wat as mitologies standhoudend en geldig aanvaar word (Reeser 2010:22-23).

Kimmel (1996:5) stel dit dat die algemeen aanvaarde beeld van die Amerikaanse man byvoorbeeld soos volg daar uitsien: jonk, getroud, wit, voorstedelik, noordelik, heteroseksueel, Protestants, vader, besit 'n tersiêre kwalifikasie, ten volle werkend, van 'n goeie kompleksie, gewig, lengte en met 'n resente rekord van sportprestasies (vgl. Behnke \& Meuser 2001:162-163). Ook Van der Watt (2007:82) verskaf voorbeelde van sosialiserende 'boodskappe' oor manlikheid wat deur ouers, onderwysers, portuurgroepe, die media en organisasies soos kerke voorgehou word: vaandeldraers, werkers, minnaars, werkgewers, geharde individue. Harris (1995:3) sluit hierby aan met 'n lys van nege dinge wat van die moderne man verwag word: wees soos jou pa, 'n getroue man, 'n goeie Samaritaan, 'n regter, 'n natuurliefhebber, 'n versorger, 'n rebel, 'n student en 'n tegnikus. Hierteenoor vind Visagie (2004:37-50) 'n aantal manlikheidsbeelde wat in die Afrikaanse literatuur tot en met 1980 voorkom, naamlik die jagter, die avonturier, die boer, die vader, die kryger, die intellektueel en die gay man. Dit behoort dus interessant te wees om hierdie manlikheidsbeelde te vergelyk met die manlikheidsbeelde in Venter se roman Santa Gamka wat in 2009 verskyn het.

Connell (1994:73) onderskei tussen vier kategorieë van manlikheid, naamlik dominant, aandadig, onderdanig en opposisioneel of protesterend. Hierdie kategorieë is egter vloeibaar en oorvleuel, en daar moet ook in gedagte gehou word dat hulle nie uitsluitlik van toepassing is op biologiese mans nie, maar dat vroue ook binne hierdie kategorieë tuisgebring kan word. Synnott (2009:26) noem op sy beurt vier ander beelde van manlikheid, naamlik die ridder, die heer (gentleman), die man wat homself opgewerk het ('a selfmade man') en meer onlangs die nuwe' man, ook bekend as l'homme rose ('n man wat nie gelukkig is met sy manlikheid nie) of die sensitiewe millennium-man. Die ridder en die krygsman is vanaf die antieke tyd bekend met die helde van Homeros, maar kom ook voor in kontemporêre heldefigure in sport en die vermaaklikheidswêreld (Synnott 2009:26). Die heer is veral geskoei op die Engelse ideaal van manlikheid waar die hoofkriteria sagmoedigheid (wat nie met swakheid verwar moet word nie), beleefdheid, integriteit, gulhartigheid en galante goeie maniere is. Enigeen kan 'n heer wees omdat dit nie aan klas, beroep of religie gekoppel is nie (Synnott 
2009:31). Die man wat homself opgewerk het, is veral 'n Amerikaanse model van manlikheid, en dit kom neer op die man wat uitgestyg het van niks tot iets (Synnott 2009:31).

Dit word duidelik dat die genoemde beelde verband hou met skripte wat binne sekere rame uitgevoer word; Jooste (2008:17) toon aan hoe sekere stereotipiese manlike arenas (lees: rame) soos werk, sport, emosies, mode en mans se verhoudings met ander mans wel bestaan. Omdat manlikheidsbeelde ook afhang van die konteks waarin hulle uitgebeeld en uitgeleef word, kan die beginsel ook na die manlikheidsbeelde oorgedra word wat binne narratiewe tekste gerepresenteer word.

Dit is, volgens Seidler (2006:45), baie belangrik vir mans om hulle posisie as mans te behou en nie aansien voor ander mans te verloor nie - veral omdat manlikhede met mekaar kompeteer en hierdie manlikheidsbeelde ten alle koste gepreserveer moet word, veral in die openbare oog. Dit geld natuurlik ook vir die beelde wat tradisioneel as alternatief beskou word. Daar word ook verwys na die radikale splitsing tussen die publieke en private sfere (lees: rame); gevolglik kan die behoefte of sosiale dwang om gepas op te tree in die openbaar, dit moeilik maak om navorsing te doen oor mans se oortuigings en verhoudings (Seidler 2006:45).

Segal (1990:100) het reeds in die vroeë negentigerjare genoem dat die dominante idee van 'n vasgestelde en klinkklare heteroseksuele manlikheid minder hegemonies is as wat dit ooit tevore was. Agtien jaar later stel Hopkins (2008:2) dit dat manlike selfdefiniëring rondom manlike gehegtheid of homososialiteit, manlike seksualiteit, manlike projeksie en identifisering, kameraadskap en de-Oedipalisering wentel. Vir manlikheid om gedekonstrueer en gedestabiliseer te word, moet die mans self hul manlikheid dekonstrueer, en daardeur word manlike identiteit groot skade aangedoen (Hopkins 2008:2). Gegewe die feit dat sekere essensiële kenmerke van die manlike psige na aggressie, dominansie en dies meer neig, moet mans vrede maak met hul kompleksiteite en teenstellings eerder as om hulleself as kulturele en sosiale mislukkings te sien en te internaliseer (Hopkins 2008:2). Volgens Reeser (2010:27) kan manlikheid in 'n krisis wees wanneer verskeie mans in 'n gegewe konteks spanning voel tussen hulself en die groter ideologieë wat in daardie konteks domineer of begin domineer.

Navorsers in die veld van genderstudies verwys reeds die afgelope paar jaar na die manlikheidskrisis wat gekenmerk word deur onstabiliteit en onsekerheid oor sosiale rolle, identiteit, seksualiteit, werk en interpersoonlike verhoudings (Frosh, Phoenix \& Pattman 2002:1). Volgens Frosh et al. (2002:1) is daar verskeie faktore wat as redes vir hierdie destabilisering van manlikheid beskou kan word. Daar is die ineenstorting van tradisionele manswerk, die groei in tegnologiese kultuur wat nie van een generasie tot die ander oorgedra kan word nie, die opkoms van die feministiese kultuur onder vroue, die meer abstrakte uitdagings vir die rasionaliteit waarmee manlikheid geïdentifiseer word en ook die verandering en selfs verwydering van die tradisionele, patriargale, dominante rol wat die man gespeel het.

Daar kan 'n logiese verband aangetoon word tussen die kognitiewe konstrukte en die uitbeelding van manlikheid in 'n roman. ' $n$ Karakter in 'n roman voer 'n sekere skript binne ' $n$ gegewe raam uit wat tot ' $n$ sekere representering van manlikheid lei. Die leser moet die romangegewens met bestaande rame en skripte in sy geheue in verband bring om die verhaal te verstaan. Indien die representasies in die roman egter meer of minder van die bestaande rame en skripte verskil, moet die leser aanpassings maak in sy arsenaal van kognitiewe inligting en prosesse. Die leser maak dan een van drie keuses deur óf meer óf minder ingrypende aanpassings aan sy of haar eie opvattings te maak, óf deur die representasie in geheel te aanvaar en sy of haar bestaande idees oor manlikheid te wysig, of om hierdie nuwe inligting heeltemal te verwerp.

\section{Lucky Marais en sy kliënte in Santa Gamka}

Vervolgens word daar geselekteerde aspekte van Santa Gamka deur Eben Venter ontleed en geïnterpreteer om die reikwydte van die kognitiewe benadering vir narratiewe tekste te toets. Vanweë die oogmerk wat hierdie artikel aan homself stel, word slegs sommige van die rame (omstandighede en plekke) en skripte (handelingsreekse) wat met manlikheid verband hou, ondersoek. Daar word eksemplaries te werk gegaan deur Lucky se optrede in sy verhouding met sommige van sy kliënte as skripte en die stoep van Eddy en Eamon en die pottebakkersoond as rame te bespreek.

Eben Venter is 'n skrywer wat subtiel te werk gaan, selfs meer as baie ander skrywers, en daarom is dit vanselfsprekend dat hy in Santa Gamka ook die leser se samewerking sal aktiveer. Die plasing van die verhaal in ' $n$ plattelandse Karoodorp, die sosiale stratifikasie van die gemeenskap, die politieke agtergrond en vele ander ruimtelike en omstandigheidsaspekte is as rame duidelik afhanklik van die interpretatiewe vaardighede en kennis van die leser. ' $n$ Uitvoerige bespreking van hierdie aspekte val egter buite die skopus van hierdie artikel, aangesien daar op Lucky Marais se manlike identiteite gefokus word.

Die skripte wat deur Lucky Marais binne bepaalde die rame uitgevoer word, gaan waarskynlik teen die verwagting van die lesers in, wat daartoe lei dat die lesers hul bestaande kognitiewe idees van die rame moet aanpas, uitbrei of wysig ten einde die roman behoorlik te kan begryp en waardeer. Die gerepresenteerde handelinge in die roman roep visies van manlikheid op wat nie noodwendig met die geykte manlike representasies in Afrikaanse literatuur of die geykte skripte in die Suid-Afrikaanse kulturele tradisie ooreenstem nie. Dit blyk duidelik as die ruimtes waarin Lucky sy sewe kliënte ontmoet en die agtergrond waarteen hy aan hul versoeke voldoen, as rame beskou word en Lucky se optrede as ongewone skripte van wat deur die kliënte van hom 
verwag word. Ter illustrasie word Lucky se verhouding met Mevrou Kristiena-Theresa, Nieta, Mister Jo D'Oliviera en Meneer Rooiboer-Kobus Lodewyk bespreek.

\section{Kliënt nr. 1: Mevrou Kristiena-Theresa}

Die verhouding tussen Lucky Marais en Mevrou KristienaTheresa is baie kompleks omdat Lucky eintlik die plek van haar seun Danie inneem wat in 'n motorongeluk gesterf het. Lucky beskryf hierdie verhouding soos volg:

Sy kyk na hom en hy wis toe sy wil sê wat sy al voorheen aan hom gesê het. Dat sy hom liefhet soos 'n seun (haar eie seun skielik weggevat), soos haar eie manskind, maar hy waardeer niks van sulke sêgoed nie. Sy wil hom intrek by haar lewe. (Venter 2009:73)

As ' $n$ vrou 'n jong man as plaasvervanger van haar seun beskou en hy die rol aanvaar, kan van beide bepaalde optrede verwag word. Daar is hier egter sowel aangetrokkenheid en toegeneentheid as afstandelikheid tussen die twee karakters, en wel van beide kante. Lucky projekteer 'n gemengde identiteit, wel in verhouding tot haar eise, maar sonder om homself prys te gee. Die leser kom agter dat Lucky Mevrou Kristiena-Theresa as 'n moederfiguur beskou wanneer hy dink: 'Klein lyk sy vanaand, kan sy ma gewees het.' (Venter 2009:177). Lucky voer ook handelinge uit wat hy weet Danie uitgevoer het, deur byvoorbeeld te lê met sy kop op sy arm gestut - 'want dis mos hoe Danie altyd gelê het' (Venter 2009:182). Sy optrede suggereer sy gewilligheid om saam te speel in die spel waarmee sy haar verlies probeer verwerk.

Hierdie simpatieke siening van Mevrou Kristiena-Theresa kontrasteer egter met die feit dat hy haar sensuele masserings gee. Hoewel die masseringshandeling nooit oorgaan tot enige seksuele daad nie, is die sensualiteit van so ' $\mathrm{n}$ aard dat dit elemente van seksualiteit suggereer. Aangesien die verhouding van moeder en seun 'n bekende raam is wat ook bekende gedragpatrone as skripte aktiveer, is die werklike verhouding tussen Lucky en Mevrou Kristiena-Theresa sterk vervreemdend.

Die karakter doen hier dus berekend gedeeltelik afstand van sy eie identiteit en pas hom aan by die raam waarin hy homself bevind. Dit is belangrik om dit te doen, aangesien dit hom in staat stel om as 'n soort diensverskaffer in sy kliënt se behoeftes te voorsien. Hierdeur word 'n ander skript en 'n ander rol vir Lucky geaktiveer. Sy manlike identiteit word meervoudig gewysig deur nie net as ' $\mathrm{n}$ rent boy Mevrou Kristiena-Theresa se wense uit te voer en as 'n persoonlike masseur op te tree nie, maar ook, soos hierbo uiteengesit, deur elemente van die afgestorwe Danie se identiteit aan te neem. Daardeur verseker hy dat hy Mevrou Kristiena-Theresa gelukkig kan hou. Die verweefdheid van ruimte, karakter en handeling in die roman word hierdeur geïllustreer.

Mevrou Kristiena-Theresa beskou Lucky as haar belegging (Venter 2009:66) en dit word van hom verwag om professioneel op te tree. Die masserings gaan juis daarom nooit oor tot enige seksuele dade nie en beide karakters hanteer die interaksie tussen hulle volgens 'n onuitgesproke self-ontwerpte stel kodes. Lucky voer hierdie skripte van sensitiwiteit, respek, agting en aandag aan haar behoeftes noukeurig, hoewel soms met innerlike weerstand, uit. Die leser kan ook agterkom dat daar 'n magspel tussen Lucky en die mevrou is: in haar motor is sy in beheer en 'maak sy die besluite' (Venter 2009:68), maar tydens die masserings hou Lucky wel daarvan om die hef in die hand te hê (Venter 2009:65). Hy is deeglik bewus van die reëls in haar huis, en ook hierdie reëls bepaal die skripte wat hy uitvoer wanneer hy in die ruimte van haar huis beweeg: 'Mevrou sal ook nooit self skink nie, skink is vir mans.' (Venter 2009:177). Mevrou Kristiena-Theresa kan beskou word as iemand wat geykte idees oor manlikheid het, aangesien sy spesifieke idees het van hoe 'n man behoort te wees. Lucky voldoen aan hierdie verwagtings wanneer hy by haar is omdat dit deel van sy werk is.

Mevrou Kristiena-Theresa en haar huis hou egter ook vir Lucky 'n voordeel in: 'As hulle bymekaar was, was daar nie 'n Bo- en Onderdorp nie. In daai nabyheid was hy op haar vlak' (Venter 2009:207). Die wedersydse afhanklikheid in die verhouding tussen die twee karakters word hier beklemtoon en dit is moontlik ' $n$ aanduiding van ' $n$ dieperliggende kwessie in Lucky se onderbewussyn wat telkens in die roman na vore kom: sy soeke na liefde en 'n moederfiguur wat nader aan die geïdealiseerde moederbeeld is. Hy stel dan ook dat hy gevoelens jeens haar het (Venter 2009:75), maar hierdie gevoelens word eerder beskryf as dié van 'n seun teenoor 'n moeder as romantiese gevoelens. Lucky soek na liefde, respek en aanvaarding en hy wil voel dat iemand hom nodig het omdat dit sy eiewaarde volgens hom verhoog. Aan die ander kant het Mevrou Kristiena-Theresa ook nodig om aangeraak te word en so vul die rent boy en sy kliënt mekaar eintlik aan. Alleenmense het dikwels ' $n$ intense behoefte aan aanraking en sy betaal iemand om dit te doen, maar daarin setel haar afhanklikheid van hom.

Die raam van Mevrou Kristiena-Theresa se huis wis die sosio-ekonomiese klasseverskille tussen hulle uit, aangesien sy buite die protokol van die klas waarvan sy deel is, optree deur van ' $\mathrm{n}$ bruin rent boy van die Onderdorp se dienste gebruik te maak. Sodoende lewer die roman ook belangrike sosiale kommentaar op die politieke agtergrond waarteen die roman afspeel, naamlik die postapartheidsera. Die feit dat ' $n$ welgestelde en gesiene wit vrou 'n bruin jongman huur om te voorsien in haar behoeftes, naamlik nabyheid en aanraking, toon dat Venter in die roman nie skroom om grense (deur die samelewing opgerig in die verlede en steeds deels in werking) te oorskry nie. Afgesien daarvan dat die grense tussen verskillende sosiale klasse oorskry word, word ras- en seksuele grense ook oorskry. Lucky beweeg van 'n raam van armoede tot binne ' $n$ raam van rykdom en doen eintlik die ondenkbare omdat hy daarin slaag om vir homself ' $n$ beter lewe te beding. Albei karakters tree buite hulle natuurlike sosiale en kulturele ruimte en ontmoet mekaar in 'n tussenwêreld, 'n liminale ruimte met sy eie stel gedragsreëls wat ' $n$ nuwe raam vorm en waarin hulle in mekaar se behoeftes voorsien. Per slot van rekening betaal Mevrou 
Kristiena-Theresa Lucky vir sy dienste. Hierdie verloop van sake druis waarskynlik in teen die verwagtingshorison van die leser en juis daarom het dit die potensiaal om die leser se bestaande idees rondom grensoorskryding te wysig. Venter herskryf ook die historiese konteks waarbinne die roman gesitueer is, deurdat hy op hierdie manier taboe-onderwerpe oopskryf.

Die verhouding tussen Lucky en Mevrou Kristiena-Theresa word wel later op ironiese manier vertroebel wanneer sy die volgende woorde uiter: 'We've got a particular bad lot here' (Venter 2009:246). Met hierdie woorde verwys sy na al die bruin en swart mense in die dorp, onder wie Lucky vanselfsprekend tel. Dit word dus duidelik dat sy nie werklik haar vooroordele oorkom nie, selfs al beskou sy Lucky as individu in ' $n$ heel ander lig. Haar opmerking ontstel hom intens en ' $n$ ommeswaai in sy teerheid teenoor haar blyk uit sy gedagtes daarna:

Sy's armsalig, sy. Hy hoor haar apartheidstories vandat hy voet in haar huis gesit het. ... Toe apartheid jare gelede gestop word, kom sy ook tot ' $n$ einde. Wat is sy nou? Sy kan nie sê nie. Sy weet miskien nie eers daar is so ' $n$ vraag nie. Sy is treurig soos by ' $n$ begrafnis. Sy sal treurig graf toe gaan. (Venter 2009:246)

Soos in Venter se Foxtrot van die vleiseters word dit duidelik dat die politieke agtergrond waarteen Santa Gamka gesitueer is, tog steeds ' $n$ bepalende invloed het op die handelinge van die karakters. Hoewel Lucky die huise van wit mense mag betree en hulle selfs op die mees intieme manier ontmoet, kan hy binne 'n oogwink gemarginaliseer word. Dit is steeds die gevolg van die politieke geladenheid van die verhoudings op grond van die onderskeide in velkleur. Deur hier ook die politieke situasie subtiel te beklemtoon toon Venter weereens hoe wyd die invloed van politiek kan uitkring en hoe mense se handelinge daardeur beïnvloed word. Die karakters word dus deur die ruimte beïnvloed waarin hulle hulleself bevind, en die lesers word eintlik gekonfronteer met die uitdaging om ' $n$ waarde-oordeel oor die situasie in die roman te vel en ook selfondersoek te doen - veral ten opsigte van hul posisie binne die historiese konteks wat deur die roman aan die orde gestel word.

Wanneer die gebeure in die roman momentum opbou, beskou Lucky Mevrou Kristiena-Theresa as 'n simbool vir wit mense wat steeds die vermoë het om 'n onderdrukkende mag uit te oefen oor die bruin en swart mense:

Op die ou end het Mevrou Kristiena-Theresa tog gewen. Sy was die een blankemens voor wie hy nie kon bly staan nie. Hy't teen haar opgestaan, ja, maar op die ou einde het sy hom getrap. (Venter 2009:256)

Lucky verwys hier na die manier waarop Mevrou KristienaTheresa hom verwerp en eintlik geïmpliseer het nadat sy deur ander mans in haar huis verkrag is. Die roman beeld hier uit hoe Lucky oor dieselfde kam as ander bruin en swart mense geskeer word bloot vanweë sy velkleur. Selfs al weet Mevrou Kristiena-Theresa dat hy hom nooit op iemand sal afdwing nie, word hy ook gebrandmerk en hy besef dat dit altyd sy lot sal wees. Dit is byna asof Venter hierdie handeling van
Mevrou Kristiena-Theresa gebruik om te toon hoe absoluut veralgemenend die koloniale blik van wit mense ná apartheid steeds is - daar word geensins onderskeid getref tussen die ras en die individue binne die ras nie.

\section{Kliënt nr. 2: Nieta}

In teenstelling met Mevrou Kristiena-Theresa is Kliënt nr. 2 'honger soos sy pa kwaad kan wees' (Venter 2009:93). Lucky besoek Nieta, die derde vrou van meneer Bradley (Venter 2009:95) wat in sy hotel op Santa Gamka in suite 17 woon, een keer per week (Venter 2009:48). Hulle het 'n vurige verhouding en waar hy Mevrou Kristiena-Theresa net moet masseer, het hy en Nieta wel elke keer seksuele omgang.

Volgens Lucky het Nieta 'dit die nodigste van al sy kliënte, maar as hy uitgevang moet word, sal hy alles verloor' (Venter 2009:92-93) want Nieta dreig hom dat, indien hy 'n woord rep oor die dinge wat in suite 17 gebeur, hy gaan 'les opsê' (Venter 2009:138). Die rede hiervoor word in die roman gestel as Nieta se gewete wat haar pla (Venter 2009:138) en dit lei tot skuldgevoelens en angs oor haar ontrou aan meneer Bradley, want 'sy's skytbang vir meneer Bradley met sy glimlag' (Venter 2009:233). Hoewel Lucky weet dat hy met vuur speel, dryf die behoefte aan 'n beter lewe hom om sy lyf te verkoop en voer hy dienooreenkomstig seksuele skripte uit sodat hy genoeg geld kan maak om uit Santa Gamka weg te kom en 'n nuwe lewe te begin. Die moontlikheid dat hulle twee betrap kan word, dien beslis as 'n spanningskeppende middel wat die leser net al meer by die plot van die roman intrek.

Venter skets egter hoe kompleks menseverhoudings kan wees wanneer dit blyk dat die verhouding tussen Lucky en Nieta die potensiaal het om tot ' $n$ werklike emosionele verbintenis te verdiep wat meer as net die fisieke behels:

Tussen hom en Nieta, soos met geen ander kliënt, was daar 'n belofte. Iets wat miskien kan gebeur. As hulle twee net kon wegkom uit die dorp na 'n plek waar daar niks oë of verwyte is nie. En geld. (Venter 2009:124)

Die universele tema van die mens se soeke na liefde en 'n plek van behoort word deur Lucky se versugting geillustreer en gee diepte aan sy karakter wat eintlik oppervlakkig kan voorkom indien slegs sy werk in ag geneem word. Soos met Mevrou Kristiena-Theresa koester Lucky ook gevoelens jeens Nieta, maar hier het dit 'n meer romantiese kleur. In 'n onbewaakte oomblik uiter Nieta egter ook haar gevoelens jeens Lucky:

Dit sal tog nooit rêrig werk tussen ons nie. ... Daar's net een mens in jou wêreld en dis Lucky Marais. Ek moet jou koop soos mens ' $n$ pakkie sigarette koop. Daar kan niks tussen ons wees nie. (Venter 2009:176)

Waar die grense tussen Lucky en Mevrou KristienaTheresa sosiale klas en die verskil in ras is, blyk dit dat Lucky eintlik sy eie grootste hindernis is. Nieta skets hom hier as 'n egosentriese mens wat nie plek vir ander mense in sy lewe het nie. Hierdie karakterbeskrywing wat eintlik 
onderspeel en net terloops genoem word in suite 17, is wel belangrik as ' $n$ aanduiding van ' $n$ bepaalde faset van Lucky se persoonlikheid. Hy het besluit om sy eie lot te bepaal en verbintenisse aan ander kan hierdie strewe ondermyn. Dit lei daartoe dat hy in ' $n$ sekere sin eintlik deels vir homself ' $n$ hindernis oplê, en homself begrens. Hy vertrou net homself en dit weerspieël sy onderliggende vrees teenoor mense met meer mag, al ontken hy dit teenoor homself en teenoor ander.

Soos met Mevrou Kristiena-Theresa bepaal Nieta ook die skripte wat in suite 17 uitgevoer mag word. So mag Lucky haar nooit op die naam noem nie, moet daar lappe oor al die spieëls in die kamer gegooi word, mag hy nie in die taal van die Onderdorp praat nie (Venter 2009:138-139) en moet hy meestal eers stort voordat hy sy dienste kan lewer (Venter 2009:231). Lucky kan natuurlik nie anders as om hierdie reëls te volg nie, aangesien sy betaling daarvan afhang. Hierdie raam in die roman ontmitologiseer die geykte manlikheidsbeeld waar die man altyd in beheer is en ook die idee dat die vrou ondergeskik aan die man moet wees. Nieta het die hef in die hand en Lucky gehoorsaam haar, nie noodwendig onwillig nie, maar sy manlike identiteit en skripte word weereens aangepas by dít wat binne die raam van suite 17 van hom verwag word.

Die manlikheidsbeeld wat hier na vore kom, verskil dan ook van die manlikheidsbeeld wat hy in Mevrou KristienaTheresa se huis projekteer. Reeds in die diskrepansies wat in Lucky se uitvoer van manlikheidskripte in die twee verskillende rame gevind word, kan die leser agterkom hoe hy, soos ' $n$ kameleon, aanpas by die omgewing waarin hy beweeg. Hoewel dit ' $n$ menslike eienskap en deel van mense se oorlewingsmeganismes in die algemeen is, is dit interessant om te sien hoe die uitspeel van genderrolle beïnvloed word deur die verskillende ruimtes en verhoudings waarin Lucky beweeg, aangesien die ruimtes en die rame en skripte binne die ruimtes die manlikheidsbeelde bepaal wat deur die karakter geprojekteer word.

\section{Kliënt nr. 3: Mister Jo D’Oliviera}

Die verskuiwing van grense in die roman duur voort wanneer Lucky besluit om sy voormalige skoolonderwyser, Mister Jo D'Oliviera, wat vir sy mislukte studies betaal het, terug te betaal met sy liggaam (Venter 2009:87). Hierdie terugbetaling behels egter geen fisieke seksuele kontak tussen die twee mans nie, maar wel dat Lucky homself moet bevredig ten aanskoue van Mister D'Oliviera, want hy weet: '[v]an al sy kliënte is Mister D'Oliviera die minste met sy lyf gepla. Kyk en verbeel is genoeg vir hom, sy waarheid hou hy binnekant homself' (Venter 2009:199, 201-202).

Die homoërotiese aard van die verhouding tussen Lucky en sy oudonderwyser verteenwoordig ' $n$ verdere grensverskuiwing in die roman, aangesien die aanvanklike verhoudings wat in die roman beskryf word, heteroseksueel van aard is. Die leser word dus hier blootgestel aan ' $n$ homoseksuele verbintenis tussen twee mans tussen wie daar nie net ' $\mathrm{n}$ groot ouderdomsgaping is nie, maar ook die alomteenwoordige verskil in ras. Verder is daar ook die verskil in status, dié tussen onderwyser en voormalige leerling, met die gepaardgaande verskil in die vlak van opleiding en gesofistikeerdheid. Venter se oopskryf van iets wat vroeër as taboe beskou sou word, is hier ook vernuwend ten opsigte van die aanvaarde verhouding tussen onderwysers en oudleerlinge en dit vereis weereens ' $n$ aanpassing van ' $n$ bestaande skript vir hierdie verhouding. Bestaande idees oor manlikheid en heteronormatiwiteit word hierdeur anders voorgestel en om van die spesifieke aard van so ' $n$ verhouding kennis te neem en dit te begryp sal ' $n$ aanpassing of wysiging van rame en skripte vereis. Meer konserwatiewe lesers sal heel waarskynlik deur hierdie tematiek en die gegewens in hierdie verhaallyn in die roman uitgedaag word.

Lucky en Mister D'Oliviera se ontmoetings vind plaas in die onderwyser se huis en word gekenmerk deur die ooreenkoms tussen hulle dat Lucky hom moet verras wanneer hy hom kom besoek (Venter 2009:211-212). Aanvanklik is dit onskuldig en blyk die verhouding tussen hulle bloot die van twee mense te wees wat mekaar intellektueel stimuleer ('tussen die rye en rye boeke' [Venter 2009:34]), maar hierdie intellektuele verbintenis word algaande vervleg met ' $n$ meer fisieke verbintenis. Die leser kan bes moontlik ook ' $n$ tipe paseun-verhouding tussen die twee mans bespeur - veral as Lucky vertel van die een bier wat Mister D'Oliviera elke dag vir hom geskink het (Venter 2009:79) en hoe Mister D'Oliviera altyd gesê het dat whisky 'n man se drank 'of liewer 'n baie ryk man s'n' is (Venter 2009:147). Lucky bly dus die seun wat slegs een bier kry om te drink. Die verstandhouding tussen die twee word as gemoedelik beskryf en die afleiding word gemaak dat Mister D'Oliviera Lucky se beste belange op die hart dra. Dit is immers Lucky wat eerste die seksuele grens tussen die twee skuif, en die oorsprong van sy gedrag kan moontlik gevind word in die ingewikkelde verhouding wat hy met sy eie pa het, sowel as die onstabiele huishouding waarin hy grootgeword het. Dié raam binne die roman word verteenwoordigend van hoe mense wat onvervuld voel en leemtes in hulle binneste dra, hul behoeftes en begeertes op ander mense projekteer. Dit word ook duidelik in die roman dat ' $n$ soeke na liefde verwarring kan meebring vir die persoon wat soek. Almal beleef konflik en vertwyfeling veral Lucky, aangesien hy nie tussen verskillende soorte liefdes kan onderskei nie. Hy beskou homself selfs as minderwaardig in vergelyking met Mister D'Oliviera: 'Hoe kan hy ooit 'n match wees vir Mister D'Oliviera?' (Venter 2009:201).

Wanneer Lucky in die pottebakkersoond is en met die dood gekonfronteer word, keer sy gedagtes na Mister D'Oliviera:

Jy wou my net leer. Maar ander goed het bygekom. Ek is so spyt. Ek is verskriklik spyt, asseblief. Ek moes jou gelos het in jou enchanting stories. Dis waar jou begeerte plek het. Nie by my kaal arm wat teen jou arm raak nie. Al daai goed. Ai tog, Mister D'Oliviera, ek huil vir jou. Mister D'Oliviera, accept my deepest sorry. (Venter 2009:225) 
Lucky se berou oor die oorskryding van die fisieke grens tussen hom en Mister D'Oliviera dien as bewys van die idee dat hy nie noodwendig die verskillende manlikheidskripte wíl uitvoer nie - vanuit sy perspektief móét hy 'n rent boy wees om geld te verdien want dit is al waarin hy werklik goed is. Hy besef ook in die pottebakkersoond dat hy in sy verhouding met die oudonderwyser werklik 'n grens oorskry het wat tot hulle albei se nadeel was. Dit toon dat hy wel buite homself kan tree en empatie kan hê met sy kliënte (soos wat hy dit ook aanvoel by Nieta, maar dit daar steeds onderdruk).

Omdat Lucky homself oefen in die verwisseling van rolle, word die oorgange van die een rol na die ander, van die een ruimte na die ander, van die een raam en die gepaardgaande skripte na die volgende, in die roman ook as bykans naatloos beskryf. Venter se subtiele uitbeelding van die verhouding tussen die karakter en die ruimte waarin hy homself bevind, is instrumenteel in die openbaring van die fyner nuanses van Lucky se karakter. Sodoende kan 'n empatiese begrip by die leser vir Lucky ontwikkel, ongeag of dit wat hy doen, goedgekeur word, al dan nie. Die hele verhaal word vanuit Lucky se perspektief aangebied (waar hy in pottebakkersoond terugdink) en hierdie werkwyse is deel van Venter se tegniek om die leser simpatiek teenoor Lucky in te stel.

\section{Kliënt nr. 5: Meneer Rooiboer-Kobus Lodewyk}

Kliënt nr. 5 is Lucky se mees onwaarskynlike kliënt. Hy word eers later in die roman een van Lucky se kliënte, hoewel Lucky reeds vroeg in die roman verwys na Rooiboer-Kobus:

Mevrou Kristiena-Theresa se standaarde is hoog, maar sy is makliker as kliënt nr. 5 wie se oë hy nog baie op sy blaaie voel as hy daar by hom wegstap. (Venter 2009:74)

Met Kliënt nr. 5 is die verhouding baie meer gekompliseerd as met enige ander een, aangesien hierdie kliënt die boer is vir wie Lucky se pa op die plaas Bethesda, waar hy grootgeword het, werk. Lucky voel in werklikheid verskeur in homself omdat Rooiboer nog altyd sy pa en hulle gesin sleg behandel het op die plaas en voel dat dit verraad sal wees teenoor sy familie om dienste aan Rooiboer-Kobus te lewer (Venter 2009:244). Andersyds kan die afleiding gemaak word dat Lucky aangetrek word deur die idee van mag wat hy oor Rooiboer sal kan uitoefen. Hy dink ook inderdaad '... toe hy hom daar so sien hurk soos ' $n$ kind, dat hy die oorhand het. Nou' (Venter 2009:191). Die spanning tussen Lucky en Rooiboer-Kobus wat reeds vroeg in die roman beskryf word (wanneer hy Lucky by die rivier betrap, Venter 2009:17), loop hoog regdeur die roman, maar Venter skryf teen die verwagtinge van die leser in wanneer hy Rooiboer-Kobus as Kliënt nr. 5 inskryf. Die verwagtingshorison word op twee maniere omvergewerp. Eerstens word die rolle omgekeer en is Lucky in hierdie verhouding in beheer. Hy het mag oor die baas van die plaas, al is dit vir 'n kort wyle. In die tweede plek gaan dit om die oopskryf van homoseksuele seksdade binne die roman. Die gemiddelde leser word moontlik in die posisie geplaas om self kognitiewe aanpassings te maak aangaande beide sake om die problematiek van die roman ten volle in die gedagtes van die leser te laat ontplooi. Indien die leser weier om hierdie inligting te verwerk, sal 'n gedeelte van die roman onontgin bly en die narratiewe ervaring sal waarskynlik minder bevredigend wees.

Rooiboer verduidelik aan Lucky waarom hy gebruik wil maak van sy dienste:

Nou ja, jy sien, die ding is so in ons huis, in ons bed kry ek nie meer wat ek wil hê nie, wat ek nodig het nie. Jy weet as mens ouer word, verander dinge. (Venter 2009:191)

Nie net word Lucky se manlikheidsbeeld beïnvloed nie, maar die manlikheidsbeeld wat Rooiboer representeer, naamlik macho-manlikheid en die Afrikanerboer-manlikheid, word albei gedestabiliseer en ondermyn. Die ondermyning is soortgelyk aan dié van Hendrik Douw Steenekamp in Foxtrot van die vleiseters, hoewel dit in Santa Gamka baie meer eksplisiet beskryf word.

Hoewel Rooiboer ook 'n man is, soos Mister D'Oliviera, is die verhouding en rede vir dienslewering tussen hom en Lucky heeltemal anders. Saam met Rooiboer kom die historiese konteks waarin die roman gesitueer is, ook na vore wanneer Lucky Rooiboer konfronteer: 'Jy kan my nie slaan nie, Meneer Kobus, daar's wette in die nuwe Suid-Afrika, jy moet die wet gehoorsaam' (Venter 2009:194). Hier bring Venter weereens op subtiele manier die hele problematiek rondom apartheid en postapartheid na vore en word die konflik tussen Lucky en Rooiboer nie net een van seksuele aard nie, maar ook van politieke aard. Venter gee egter nou die mag oor aan Lucky en hy kan Rooiboer (letterlik) slaan, selfs al verskaf dit nie pyn nie, maar plesier aan hom. Die verskuiwing van mag na die hande van die Ander kan beskou word as 'n poging deur die outeur om die ekwilibrium van regverdigheid weer te herstel.

Venter is in die roman wel duidelik deurgaans sensitief vir die rol wat manlikheid in alle verhoudinge speel. In hierdie verhouding word 'n soort magstryd, wat gewoonlik verhoudinge tussen heteroseksuele mans kenmerk, in 'n ander raamwerk geplaas. Lucky se mag oor Rooiboer berus nie op die gewone soort kompetisie tussen mans nie, maar op Rooiboer as afhanklikheid van sy dienste en veral op sy kennis van die valsheid van Rooiboer se openbare beeld. Daarom probeer Lucky om Rooiboer se manlikheidsbeeld skade te berokken wanneer hy van sy aanvallers vlug: 'Sy eer wat van hom as boer verwag word en vernaamste sy manlikheid, al die goete op die spel' (Venter 2009:265). Lucky se kennis van die eer van die boere en ryk mense bemagtig hom en dien as 'n wapen wat hy kan gebruik. Hierdie kennis kan Lucky egter nie van sy agtervolgers red nie want hy word gewoon word deur sy aanvallers doodgepraat. Rooiboer kry 'n deel van sy mag terug en slaag daarin om Lucky uit te skakel as hy hom betyds laat swyg.

Die uitbeelding van elkeen van hierdie verhoudings verskuif grense, nie net in die tradisie van die Afrikaanse roman nie, maar ook waarskynlik vir baie lesers. Lucky se dienste aan sy 
ander drie kliënte kan op dieselfde manier ontleed word in terme van die ruimtes waarin die karakters hulle bevind en die rame en skripte wat hulle skep of aanvaar en wat hulle optrede bepaal. Mevrou Jolene September, die munisipale bestuurder gebruik Lucky se dienste openlik, want sy sien niks verkeerds in dinge, nie, maar sy is wel 'n invloedryke persoon deur wie hy tot die wêreld van nuwe magstrukture in die nuwe Suid-Afrika toegang kry. Antie Yvette is die een wat hom in die wêreld van sensualiteit en seksualiteit inlei (in der waarheid van sy onskuld ontneem, maar hom wel bewus maak van die besondere 'talent' wat hy het vir liggaamlikheid), terwyl die verhouding met Cloëtte eintlik die enigste is wat binne die normale verwagtingshorison val, naamlik dié van twee jongmense van gelyke status wat tot mekaar aangetrokke voel. Maar Lucky se bepaalde ambisie om sy talent, sy 'sterkte' waarvan hy by antie Yvette bewus word, te gebruik om vooruit te kom in die lewe, weerhou hom daarvan om hierdie verhouding verder te ontwikkel.

\section{Eddy en Eamonn se stoep as ontvlugtingsraam}

Die stoep van die huis wat Eddy en Eamonn tydens hul verblyf in Santa Gamka huur, word in die roman voorgestel as die enigste ruimte, behalwe die pottebakkersoond, waarin Lucky homself kan wees. Lucky glo dat die twee Iere gestuur is 'om een ding op aarde klaar te maak en dis om Lucky Marais weg te vat' (Venter 2009:45) en hy sê self dat Eddy en Eamonn baie vinnig die 'hoofkommedore oor sy lewe' (Venter 2009:45) geword het. Vir hom word die stoep 'n toevlug waar hy elke aand ná hy by een van sy kliënte was, oor die toekoms kan droom, met 'n yskoue bier kan ontspan, kalmte kan ervaar en aan die twee Iere vertel met wie hy gewerk en wat hy met hulle gedoen het (Venter 2009:98). Die atmosfeer op die stoep wat Venter skep, is een van gemoedelikheid, kameraadskap en onvoorwaardelike positiewe aanvaarding. Lucky voel veilig by die twee mans en dit is by hulle dat hy 'n groot waarheid leer:

Of wou hulle miskien vir hom inlywe in hulle geheim: Jy kan lewe, jy kan asemhaal, jy kan eet en werk, naai, alles op jou eie houtjie, net joune, en niemand op hierdie aarde hoef eers daarvan te weet nie. Nie die dorp, nie die skinnerige mense, nie die familie nie. Net jy en met wie jy wil wees sonder dat enigiets taais aan jou vassit. (Venter 2009:100)

Met hierdie wysheid skryf Venter ook hoop in die roman in en voel die leser dat daar wel uitkomkans vir Lucky is. Hy hoef nie vir ewig vasgevang te wees in sy omstandighede nie, maar kan daaruit ontsnap. Weereens is dit asof Venter hier empatie by die leser bewerkstellig en hom of haar saam met die karakter drome van 'n beter lewe laat droom.

By Eddy en Eamon kan Lucky geborge voel, want hy kan daar wegkom van sy gewete en die gedagtes wat hom bekommer (Venter 2009:121). Aanhalings soos '[o]p daai stoep het hy gaan skuil, oor alles daar kon hy vry praat' (Venter 2009:121) en '[d]aai stoep kon stiltes vat' (Venter 2009:123) dui op Lucky se verknogtheid aan die stoep as 'n raam waarbinne bepaalde optredes aanvaarbaar en moontlik is. Dit het 'n heilsame effek op hom. Te midde van al die kompleksiteite van die plaas, die Bodorp en die Onderdorp, skep Venter 'n oase waar Lucky kan herlaai saam met die enigste twee mense vir wie hy lief geword het, selfs 'al weet hy self nie wat liefde is nie' (Venter 2009:123). Die leser self word ' $n$ verposing gegun van die verskillende fokalisasiehoeke, die ruimteverwisselings en die groot hoeveelhede inligting wat verwerk moet word wanneer Lucky op Eddy en Eamonn se stoep is, aangesien baie van die dinge wat Lucky ervaar, hier vertel en toegelig word ten einde die karakter se identiteit en persoonlikheid nog beter te teken.

Die gemaklikheid en ongekompliseerdheid van die skripte wat hy uitvoer op die stoep, toon aan die leser dat Lucky hier homself is. Hierdie ontspanne manlikheid is wat hy dan ook self beskou as wat hy werklik is en wil wees. Die belangrikste aspek van onthulling aangaande Lucky Marais is egter die feit dat die hele roman vanuit sy perspektief aangebied word as hy in die pottebakkersoond vasgekeer is.

\section{Die pottebakkersoond as eksistensiële raam}

Reeds aan die begin van die roman word dit duidelik dat die pottebakkersoond van Alexandra, waarin Lucky deur Rooiboer-Kobus, meneer Bradley (die hoteleienaar) en Wella, die dameskroegman in die hotel gegooi word, 'n betekenisvolle ruimte in die roman is. Hierdie ruimte word trouens die sentrale ruimte en dus ook die belangrikste raam in die roman.

Die oond as sodanig verkry simboliese waarde, aangesien erdewerk in ' $n$ pottebakkersoond hard gebak word, en vir Lucky word dit ' $n$ loutering. Hy dink dat hy gaan sterf en dit lei daartoe dat hy sy verlede herroep en herbedink, maar dan wel met die insig en verhoogde persepsie wat deur angs en die vermoede van die einde van sy lewe teweeggebring word. Soos hy die minute tot sy dood aftel, kry hy terugflitse wat as analepsisse in die hoofverhaallyn van die roman ingebed word. Op hierdie manier word die leser die geleentheid gegun om toegang tot Lucky se denkwêreld te kry en te sien wat sy perspektief op die lewe en die wêreld is. Die oond kan dus as 'n eksistensiële raam beskou word waarin die konfrontasie met die dood die eerlike beskouing van 'n hele lewe ontlok en moontlik maak. Dit is belangrik dat die inligting in die roman deur Lucky gefokaliseer word - jy leer hom dus ken deur sy eie visie op homself: sy berekendheid, sy inskiklikheid, sy vermoë om homself ondergeskik te stel sowel as om ander te manipuleer. Hy bedink of beskryf homself dus, maar interessant genoeg is hierdie strategie van die outeur ook deel daarvan om die leser in Lucky se kring in te trek, ter wille van sy storie sowel as objek van sy sjarme en swakhede.

Die sekondêre fokalisasieverskuiwings waarmee Venter regdeur die roman werk, gee die leser ' $n$ kans om meer te wete te kom oor die manier waarop ander mense Lucky in verskillende ruimtes en in verskillende rolle sien optree. Hy beweeg in en uit verskillende rame en rolle en dit bring ' $n$ 
beter begrip en empatie mee ten opsigte van die skripte wat hy uitvoer. Dit is maklik om veroordelend te wees teenoor die feit dat hy ' $\mathrm{n}$ rent boy is, maar soos die roman vorder en ekstra inligting aan die leser bekend word, begin die leser om sy of haar bestaande idees oor die karakter en die skripte wat hy uitvoer, aan te pas en die karakter beter te verstaan. Lucky se eie sowel as ander perspektiewe op sy karakter word dus betrek, maar uiteindelik is die leser saam met Lucky in die oond.

Die subteks in die uitbeelding van al die verhoudinge waarin Lucky te staan kom, is dat hy daarna strewe om in beheer te wees - daarom laat hy hom manipuleer en onderwerp hy hom tot sy eie voordeel. Hy laat hom nie verlei om van sy keuses af te wyk nie. Maar in die oond is hy magteloos, ook met homself gekonfronteer. Hierdie situasie en Lucky se magteloosheid destabiliseer ook die hegemoniese manlikheidsbeeld, aangesien die man in hierdie geval nie in beheer van die situasie is nie. Dit ondermyn verder die geykte siening dat mans nie eintlik veronderstel is om introspeksie te doen of in voeling met hul emosionele wêreld te wees nie. Soos in Venter se roman Ek stamel ek sterwe is die moontlikheid van dood 'n gelykmaker in dié opsig dat Lucky eintlik gestroop word van sy manlikheid, van sy selfbeeld en van kunsmatige projeksies van homself en dat die oorblywende persona op die ou end slegs ' $n$ mens is met die mees primitiewe angs vir die naderende dood: 'Spoke. Syne. Hoe kan hy nou met hulle klaarmaak as hy nie in sy lewe kon nie' (Venter 2009:60).

Een van die belangrikste gedagtes wat by Lucky opkom terwyl hy in die oond is, is die herinnering aan die vertelling van sy geboorte en hoe sy tantes hom beskryf het: 'Jy't ná apartheid aangekom, jy is vry, hou jou kordaat.' (Venter 2009:9). Hierdie woorde aan die begin van die roman blyk ironies te wees, want hoewel Lucky deur sy kordaatheid grense binne die roman verskuif, is daardie grense slegs tydelik verskuif, aangesien hy aan die einde steeds op grond van sy velkleur geoordeel word. Lucky begryp baie dinge in die oond: dat hy op ' $n$ bepaalde manier sterk was; dat hy hom in uiteenlopende situasies kon aanpas ter wille van sy eie siening; van vooruitgang, dat hy wel oomblikke van rus en ontspanne selfwees nodig gehad het, maar hy weet ook dat hy nie van homself kon ontsnap nie. Nou besef hy sy onreg aan Mister D'Oliviera, hy sien die weerloosheid van vroue soos Mevrou Kristiena-Theresa en Nieta en hy begryp die mengsel van haat en afhanklikheid en weerloosheid van Rooiboer. Die vrug van Lucky se insig in homself is inderdaad die roman self omdat die hele verhaal deur sy perspektief gefilter is. Ten slotte is daar ook die polities-ideologiese insig wat aan die leser oorgedra word: dat Lucky vry is of homself van apartheid en rassestereotipes kon bevry, is ' $n$ waanidee. Hierdie raam en die gepaardgaande skripte bly in werking en al die ondermynings en grensoorskrydings gebeur as ' $t$ ware daarbinne. Want uiteindelik moet Lucky vlug. Venter toon hiermee ook aan hoe kompleks die uitwerking en nawerking van die politieke en ideologiese denkpatrone van die apartheidsera op die Suid-Afrikaanse gemeenskap was en steeds is. Daar is by almal, by Lucky én sy kliënte, 'n eksistensiële bevraagtekening van hulself en hul plek in die wêreld.

In die oond bevraagteken Lucky sy bestaan en plek in die wêreld en doen introspeksie oor sy verlede. Sy herinneringe kom staan glashelder voor hom. Hoewel Lucky se gedagtes en motiverings nie uitvoerig beskryf word nie, leer lesers hom ken uit sy optrede teenoor sy kliënte en dit is wat hy in die pottebakkersoond herroep. Dit is wel so dat Lucky as fokalisator optree en omdat die inligting deur hom gefilter word, is dit subjektief en daarom nie heeltemal betroubaar is nie. Nogtans is die herroeping in geheel wel ' $n$ insiggewende beeld van die aard van die karakter omdat hy homself in al sy rolle en in al die fases van sy ontwikkeling sien. Lucky herroep die inligting en die leser kan dit interpreteer.

Wanneer Lucky vertel van sy kanse wat opgeraak het, word die selfvertroue waarmee hy die skripte in die onderskeie rame uitvoer, gerelativeer. Daar is kontrasterende boodskappe opgesluit in sy herinneringe: hy is ' $n$ professionele werker wat emosie uit sy take uitsluit, maar hy weet dat hy ook ' $n$ kansvatter is. Hy is wel deeglik bewus van die rede waarom hy hom bevind waar hy is hy moes geld maak sodat hy uit armoede kon ontsnap. Hierdie 'ontsnapping' herinner baie aan Petrus Steenekamp se idees rondom die ontsnapping van die plaasraam waarin hy homself bevind (Foxtrot van die vleiseters), sowel as aan Konstant Wasserman se wegbreek van die plaas na Australië (Ek stamel ek sterwe) en blyk 'n skript te wees wat deur verskillende manlike karakters in Venter se oeuvre as geheel uitgevoer word.

Hoewel Lucky tydens die periode van sy lewe wat hy as rent boy gewerk het, gedink het dat hy grense oorskry, dat hy in beheer is en homself weerhou van alles wat sy koers sal verander, dat hy doen wat nodig is vir sy eie doel, besef hy in die oond dat alles wel steeds relatief is. Uiteindelik kon hy nie alles beheer nie. Sy lewe word gered deur die kragonderbreking maar hy weet sy lewe in Santa Gamka is vir altyd verby. Dat hy uiteindelik ook deur Eddy en Eamonn in die steek gelaat word en weer op homself aangewese bly in die vreemde, is dan ook die finale waarheid.

\section{Gevolgtrekking}

In Santa Gamka skryf Venter taboe-onderwerpe en sosiomaatskaplike vraagstukke oop. Hy het deernis met sy karakters en veroordeel hulle nie, maar probeer juis só skryf dat die leser ook empatie ontwikkel met die karakters en die situasies waarin hulle hulle bevind. Lucky se kliënte wissel in ouderdomme, ras en geslag, maar dit is duidelik dat dit vir hom nie oor die seksdaad gaan nie. Veel eerder word seks beskou as die middel waarmee hy sy doelwit wil bereik, naamlik om genoeg geld te maak sodat hy Santa Gamka kan verlaat en oorsee gaan saam met Eddy en Eamonn. Binne die raamwerke waarin sy kliënte is, word hy deur hulle aangesê 
wat om te doen en watter reëls daar geld. Hy verwissel dus deurgaans van identiteit, en die skripte wat hy uitvoer om sy kliënte gelukkig te hou, word bepaal deur die rame waarin hy hom bevind. Soos in die voorafgaande ontledings uitgewys is, kom daar in al sy verhoudinge egter ook ander aspekte van sy persoonlikheid en ook sy psigiese behoeftes na vore. Dit lei tot die representasies van veelfasettige manlikheidsbeelde, en sodoende word Lucky se identiteit en persoonlikheid deur Venter gekompliseer op 'n manier wat vir lesers boeiend is.

Eddy en Eamonn se stoep dien nie net as ontvlugtingsraam vir Lucky nie, maar ook as 'n verposing vir die leser waartydens daar bestek van die verwikkelinge binne die roman opgeneem kan word. Die stoep bied aan Lucky ontvlugting en ook ' $n$ plek waar hy op byna terapeutiese manier afstand kan verkry tussen hom en sy kliënte, veral omdat dit in die aande is en hy op die stoep verskans is van die dorp se nuuskierige oë. Hy word ook byna weer soos 'n klein seuntjie in die teenwoordigheid van die ouer Ierse mans en koester die toegeneentheid en beskerming wat hy op die stoep ervaar. Die manlikheidsbeeld wat hy dus hier representeer, verskil van al die ander rame waarin hy beweeg in dié opsig dat hy binne hierdie raam die naaste is aan die beeld van ' $n$ seuntjie wat net na onvoorwaardelike aanvaarding en liefde smag.

Die pottebakkersoond as eksistensiële raam dien as 'n ruimte wat deur Venter geskep word om die leser toegang tot Lucky se wêreld te gee ten einde hom beter te kan verstaan. Die leser word dus ingetrek deur die inligting wat sodoende ingewin word en met inagneming dat dit vanuit Lucky se fokalisasiehoek vertel word, moet die leser die gegewens interpreteer. Die feit dat hierdie man sy lewe in oënskou moet neem terwyl hy, wat juis interpersoonlike dienste lewer, alleen in die oond is en ook dan uiteindelik alleen op 'n lughawe in 'n vreemde land agterbly, dui nie net op die siening dat die mens gevange in homself bly nie, maar dat hy ook uiteindelik net homself het waarop hy hom kan verlaat.

Lucky Marais is soos ' $n$ kameleon wat van gedaante verwissel, veral wat betref die manlikheidsbeelde wat hy projekteer deur die skripte wat hy uitvoer binne die situasies waarin hy hom bevind. Manlikheidsbeelde wat deur Lucky Marais geprojekteer word in die roman, sluit dus in die rent boy, die seun, die oudste kind, die vriend, die versorger, die masseur, die luisteraar, die vlugteling, die beskuldige, die denker, die dromer, die intellektueel en die student. Uiteindelik is hy ook die sondebok wat geoffer moet word vir die foute van die gemeenskap. En hy bly steeds net op homself aangewese.

In die laaste paar bladsye van die roman word hy soos volg beskryf:

Want jy is Lucky Marais. Jy moet dit vasknoop aan jou oor, niks mag jou onderkry nie. Nie mense met mag en geld en die wil om te oorheers nie, sulke mense kry jy oral, ook in St. Gamka. Luister vir my, Lucky, sulke mense is daartoe in staat om jou te intimideer. Voor jy weet, buig jy voor hulle. Vrees hulle nie, nóg enige lot wat jou kant toe kom. Niks mag jou ooit laat kapituleer nie. Jy't van nêrens gekom en jy't uitgestyg, want jy kon. (Venter 2009:225)

Die sentrale argument van hierdie artikel is dat Eben Venter tegnies ' $n$ uiters vaardige outeur is wat bewustelik en op interessante manier die kwessies rondom manlikheid in sy romanoeuvre uitbeeld en problematiseer. Vanuit die kognitiewe narratologiese teorie word sekere rame en skripte van manlikheid binne die teks geaktiveer en daarna verder gekwalifiseer en/of ondermyn. Die kwalifisering of ondermyning (meestal laasgenoemde) lei tot die representasie van manlikheidsbeelde wat strydig is met die stereotipiese heteronormatiewe manlikheidsbeelde wat gewoonlik in Afrikaanse literatuur gevind word. Venter het ' $n$ fyn aanvoeling en waardering vir menslikheid in die breë en met hierdie artikel word gepoog om 'n bydrae te lewer deur veral te fokus op die manifestasies van menslikheid soos dit in verskillende manlikheidsvorme in Santa Gamka aanwesig is.

Die ander oogmerk van die artikel was om die moontlikhede van die kognitiewe narratologie as literêre benadering te ondersoek. Hoewel die argument dikwels gestel word dat rame en skripte slegs nuwe terme vir bestaande konsepte en interpretasietegnieke is wat ook in ander teoretiese benaderings voorkom, is dit wel nuttig om sowel die uitgebeelde materiaal in die teks as die skryfen verstaanprosesse van die roman te benader vanuit onderliggende kognitiewe en mentale prosesse. Die kognitiewe versmelting van die manier waarop die karakter dink en optree met die bepaalde konteks waarin hy homself bevind soos in hierdie roman, bied egter weldeeglik die moontlikheid tot vrugbare ontleding. Die benadering maak dit moontlik om sosiale konstrukte en denkwyses in verband te bring met menslike handelingspatrone en die motivering daarvoor, maar dit gee ook veral insig in die manier waarop menslike gedrag verstaan en beoordeel word. Dit is wel waar dat kognitiewe narratologie nog in ' $n$ ontwikkelingstadium is, maar daar word baie daaroor geskryf en boeiende navorsing met behulp daarvan gedoen. Die benadering verskaf daarom wel bruikbare en omlynde terme en begrippe aan die hand waarvan komplekse verhaalstrukture ontleed en geïnterpreteer kan word. Vanselfsprekend is baie van die terme en konsepte metafore soos wat alle teorieë van metaforiese taal gebruik maak, maar die kognitiewe benadering word wel gekenmerk deur 'n strewe na helderheid omdat dit juis ingestel is daarop om mentale prosesse te verstaan. In dié opsig het die ondersoek waaruit hierdie artikel voortkom wel tot die gevolgtrekking kon kom dat die benadering nuttig is en tot nuwe insig in tekste kan lei.

\section{Erkennings Mededingende belang}

Die outeurs verklaar dat hulle geen finansiële of persoonlike verhouding(s) het wat hulle op 'n onvanpaste manier in die skryf van hierdie artikel kon beïnvloed het nie. 


\section{Outeursbydraes}

S.v.Z. (Noordwes-Universiteit) het die navorsing gedoen en die aanvanklike artikel geskryf. H.d.P. (NoordwesUniversiteit) het die artikel geredigeer en dele van die geredigeerde weergawe herskryf.

\section{Literatuurverwysings}

Abelson, R.P., 1981, 'Psychological status of the script concept', American Psychologist 36(7), 715-729. http://dx.doi.org/10.1037/0003-066X.36.7.715

Behnke, C. \& Meuser, M., 2001, 'Gender and habitus: Fundamental securities and crisis tendencies among men', in B. Baron \& H. Kotthoff (eds.), Gender in interaction: Perspectives on femininity and masculinity in ethnography and discourse, $\mathrm{pp}$. 153-173, John Benjamin Publishers, Amsterdam.

Connell, R.W., 1994, Masculinities, Polity, Cambridge.

Connell, R.W., 2001, 'Masculinities and men's health', in B. Baron \& H. Kotthoff (eds.), Gender in interaction: Perspectives on femininity and masculinity in ethnography and discourse, pp. 139-152, John Benjamin Publishers, Amsterdam.

Emmott, C., 1994, 'Frames of reference: Contextual monitoring and narrative discourse', in M. Coulthard (ed.), Advances in written text analysis, pp. 157-166, Routledge, London.

Emmott, C. \& Alexander, M., 2011, 'Schemata', in P. Hühn, J.C. Meister, J. Pier \& W. Scmid (eds.), The living handbook of narratology, viewed 10 September 2010 from http://hup.sub.uni-hamburg.de//hn/index.php?title=Schemata\&oldid=1075

Frosh, S., Phoenix, A. \& Pattman, R., 2002, Young masculinities, Palgrave, Basingstoke.

Gerrig, R.J. \& Egidi, G., 2003, 'Cognitive psychological foundations of narrative experiences', in D. Herman (ed.), Narrative theory and the cognitive sciences, pp. 33-55, Center for the study of language and information, Stanford.

Harris, I.M., 1995, Messages men hear: Constructing masculinities, Taylor \& Francis, London.

Herman, D., 1997, 'Scripts, sequences, and stories: Elements of a postclassical narratology', Publication of the Modern Language Association of America 112(5), 1046-1059. http://dx.doi.org/10.2307/463482

Herman, D., 2003, Narrative theory and the cognitive sciences, Center for the study of language and information, Stanford.

Hopkins, D., 2008, Dada's boys: Masculinity after Duchamp, Yale University Press, London.
Jahn, M., 1997, 'Frames, preferences, and the reading of third-person narratives: Towards a cognitive narratology', Poetics Today 18(4), 441-468. http://dx.doi. org/10.2307/1773182

Jahn, M., 1999, "'Speak friend, and enter": Garden paths, artificial intelligence, and cognitive narratology', in D. Herman (ed.), Narratologies: New perspectives on narrative analysis, pp. 167-194, Ohio State University Press, Columbus. http:// dx.doi.org/10.2307/1773182

Jooste, J., 2008, 'Professional men's expressions of their masculine identity', MA thesis, University of the Witwatersrand, Johannesburg.

Kimmel, M., 1996, Manhood in America: A cultural history, Free Press, New York.

Margolin, U., 2003, 'Cognitive science, the thinking mind, and literary narrative', in D. Herman (ed.), Narrative theory and the cognitive sciences, pp. 271-294, Center for the study of language and information, Oxford.

Mercadal, D., 1990, A dictionary of artificial intelligence, Van Nostrand, New York.

Minsky, M., 1974, A framework for representing knowledge, Massachusetts Institute of Technology, Massachusetts.

Palmer, A., 2004, Fictional minds, University of Nebraska Press, Lincoln.

Reeser, T.W., 2010, Masculinities in theory: An introduction, Wiley-Blackwell, West Sussex. http://dx.doi.org/10.1002/9781444317312

Rimmon-Kenan, S., 1994, Narrative fiction: Contemporary poetics, Routledge, London.

Schank, R.C. \& Abelson, R.P., 1975, 'Scripts, plans, and knowledge', Advance papers of the fourth International Joint Conference on Artificial Intelligence, Tbilisi, Georgia, USSR, 3-8 September, pp. 151-157.

Segal, L., 1990, Slow motion: Changing masculinities, changing men, Virago Press, Palgrave.

Seidler, V.J., 2006, Young men and masculinities: Global cultures and intimate lives', Zed Books, London.

Synnott, A., 2009, Re-thinking men: Heroes, villains and victims, Ashgate Publishing, Surrey.

Van der Watt, J.S., 2007, 'Images of men and masculinities within cultural contexts: A pastoral assessment', PhD dissertation, University of Stellenbosch, Stellenbosch.

Van Zyl, S., 2014, 'Die representasie van veelfasettige manlikheidsbeelde in Eben Venter se romanoeuvre', MA-verhandeling, Noordwes-Universiteit Potchefstroomkampus, Potchefstroom.

Venter, E., 2009, Santa Gamka, Tafelberg NB-Uitgewers, Kaapstad.

Visagie, A.G., 2004, 'Manlike subjektiwiteit in die Afrikaanse prosa 1980-2000', PhD-proefskrif, Universiteit van Stellenbosch, Stellenbosch. 